\title{
Evaluation of Blossom Thinning Spray Timing Strategies in Apple
}

\author{
W. Chester Allen ${ }^{1}$, Tom Kon ${ }^{2}$ and Sherif M. Sherif ${ }^{1, *}$ \\ 1 Alson H. Smith, Jr. Agricultural Research and Extension Center, School of Plant and Environmental Sciences, \\ Virginia Tech, Winchester, VA 22602, USA; allen97@vt.edu \\ 2 Mountain Horticultural Crops Research and Extension Center, Department of Horticultural Science, \\ North Carolina State University, Mills River, NC 28759, USA; tom_kon@ncsu.edu \\ * Correspondence: ssherif@vt.edu; Tel.: +1-(540)-232-6035
}

check for updates

Citation: Allen, W.C.; Kon, T.; Sherif, S.M. Evaluation of Blossom Thinning Spray Timing Strategies in Apple. Horticulturae 2021, 7, 308. https:/ / doi.org/10.3390/horticulturae7090308

Academic Editor: Riccardo Lo Bianco

Received: 11 August 2021

Accepted: 10 September 2021

Published: 13 September 2021

Publisher's Note: MDPI stays neutral with regard to jurisdictional claims in published maps and institutional affiliations.

Copyright: (c) 2021 by the authors. Licensee MDPI, Basel, Switzerland. This article is an open access article distributed under the terms and conditions of the Creative Commons Attribution (CC BY) license (https:// creativecommons.org/licenses/by/ $4.0 /)$.

\begin{abstract}
In the eastern USA and several other apple-growing regions, apple blossom thinning using lime sulfur is a relatively new crop load management strategy. This study sought to evaluate how application timing of lime sulfur + stylet oil blossom thinning sprays would influence thinning efficacy and crop safety of 'Gala' apples. This project occurred at two locations in the USA, Winchester, Virginia, and Mills River, North Carolina, during the 2019 growing season. Two main timing strategies were assessed: (1) model-guided sprays with the pollen tube growth model (PTGM), (2) fixed spray intervals with the first spray applied at a specified percentage of open bloom (20\% vs. $80 \%)$, and the second spray applied at a reapplication interval ( $48 \mathrm{~h}$ vs. $72 \mathrm{~h}$ ). Model-guided and $20 \%$ open bloom + 48-h treatments reduced fruit set and increased fruit weight, diameter, and length at both sites. Treatments with a delayed first spray at $80 \%$ open bloom or a more extended second reapplication of $72 \mathrm{~h}$ were generally ineffective. There was no conclusive evidence that lime sulfur + stylet oil blossom thinning spray timing influenced russet incidence/severity or leaf phytotoxicity. This study demonstrated that effective and safe blossom thinning can be obtained from applying two sprays at $20 \%$ open bloom and $48 \mathrm{~h}$ thereafter or using the PTGM.
\end{abstract}

Keywords: apple; blossom thinning; lime sulfur; pollen tube growth model; crop load management

\section{Introduction}

Under natural conditions, 8-10\% of apple blossoms develop into fruit; however, an ideal crop is obtained when approximately $5 \%$ of the blossoms set fruit [1]. When proper thinning is implemented, the crop load is reduced to a level which balances tree carbohydrate usage between developing fruit in the current year and flower bud development for the following crop. Consequently, thinning improves return bloom for the following year which promotes annual bearing [2-4]. Additionally, thinning improves fruit quality traits such as size and coloration by allowing carbohydrates to be channeled into fewer fruits and increasing fruit spacing to improve color development [5].

Commercial apple growers make many important annual management decisions which directly impact the production and sustainability of their orchards. Thinning decisions are considered to be among the most important since they directly impact yield, fruit quality, profitability, and growing habit. Post-bloom chemical fruit thinning using plant growth regulators and carbamate insecticides are the main thinning methods to reduce crop load in apple orchards [6-8]. However, there are numerous external factors such as weather conditions that greatly impact the efficacy of post-bloom fruit thinning spray applications $[6,9,10]$. One alternative thinning practice is chemical blossom thinning. Unlike post-bloom chemical fruit thinning, chemical blossom thinning uses chemicals applied during bloom to reduce the crop load by preventing the fertilization of a percentage of the flowers [11]. Only a few chemicals obtained a label for apple blossom thinning in the USA. These include dinitro-o-cresylate (DNOC), sulfcarbamide, pelargonic acid, endothall 
and liquid lime sulfur (LLS) [11-15]. However, due to phytotoxicity, variability in thinning efficacy, and spray tank mixing issues, none of these chemicals except LLS is currently labelled for chemical blossom thinning in the USA [11,16].

Timing of blossom thinning applications is critical for optimal results [17]. Currently, there are two major methods of timing blossom thinning sprays: (1) visual observation of the percentage of open blossoms and (2) model-guided spray method using the pollen tube growth model (PTGM). Using the visual observation method requires growers to visually estimate the percentage of open bloom frequently during the bloom period. Common spray applications timings with visual observation method include $20 \%, 40 \%, 60 \%, 80 \%$, and $100 \%$ open bloom with single or multiple applications occurring [18]. However, the recommended percentage of open bloom for timing a spray application can vary depending on the chemical blossom thinner used and the source of information. In addition, variable thinning outcomes can result since pollen tubes are capable of reaching the base of the style within $48 \mathrm{~h} \mathrm{[19]}$, thereby resulting in fertilization and rendering the blossom thinning spray ineffective. As a result, visual observation of open bloom for timing blossom thinning sprays is a subjective method compared to model-guided bloom thinning.

In order to find a method to determine optimum application timings, another line of research was initiated by researchers at Virginia Tech University who invested into developing a decision-making tool. The work of Yoder and colleagues in 2009 demonstrated that pollen tube growth rates were regulated by genotype and temperature [19]. Further work by DeLong et al. [20] showed that a three-factor relationship between paternal pollen tube growth rates, maternal cultivar, and temperature collectively determined the time required for fertilization. From this and other research, the PTGM was developed for seven varieties ('Red Delicious', 'Golden Delicious', 'Honeycrisp', 'Granny Smith', 'Cripps Pink', 'Gala', and 'Fuji'). In apple, every fruiting spur produces a cluster of 5-6 blossoms, with the central one being referred to as the king blossom. Early investigations with the PTGM indicated that application timing guided by the model resulted in the desired effect of allowing the fertilization of the majority of the king blossom ( $85 \%$ fertilized) and preventing the fertilization of the majority of the side blossoms ( $20 \%$ fertilized) in Gala orchard blocks [21]. After extensive field testing in Washington, the PTGM was publicly made available on the AgWeatherNet website for West Coast producers [22] and the NEWA website for East Coast producers [23].

Although the PTGM can assist growers in timing blossom thinning sprays, there are several limitations. First, the model does not compensate for the varying efficacy and modes of actions of different blossom thinning agents and/or surfactant combinations. The PTGM was developed using LLS combined with fish oil, since it was the preferred blossom thinning material and adjuvant in WA [21]. Additionally, the current model utilizes the pollen tube growth rate of the pollinizer 'Snowdrift' for making fertilization timing predictions [20]. With many apple orchards on the East Coast relying on several other pollinizer cultivars (i.e., 'Manchurian', 'Indian Summer', 'Evereste', etc.) and even production cultivars (i.e., 'Golden Delicious', 'Fuji', etc.) for pollen sources, the accuracy of the PTGM will vary from block to block depending on the dominant pollen source. Furthermore, the PTGM is currently available for seven different varieties [5]. Many apple growers have more than seven varieties planted. Although growers could attempt to match varieties not listed on the PTGM to the closest variety based on parentage, different varietal responses have been recognized which could result in inaccurate model predictions [21]. Finally, recommended use of the PTGM requires a significant amount of time for the growers to collect flowers, measure style length, input necessary data, and frequently monitor the model. This can be especially challenging for growers who have large acreage and multiple varieties and/or blocks.

With limitations to model-guided bloom thinning and few sound science-based guidelines for using the visual observation of open blooms to time sprays, there is a warranted need for alternative lime sulfur blossom thinning timing strategies. In the present study, two main lime sulfur blossom thinning application timing strategies were evaluated and 
compared. One strategy was based on model-guided bloom thinning applications using the PTGM to determine application timing and frequency. The other strategy was based on scheduled applications. For the schedule-based treatments, initial spray application timing was based on the percentage of open bloom (i.e., $20 \%$ open bloom vs. $80 \%$ open bloom) and subsequent blossom thinning spray timing was based on fixed time intervals (i.e., $48 \mathrm{~h}$ vs. $72 \mathrm{~h}$ ). This research sought to evaluate how: (1) initial lime sulfur blossom thinning sprays applied according to the percentage of open bloom and (2) subsequent lime sulfur blossom thinning sprays applied according to time intervals collectively impact fruit set, crop density yield, fruit russet, etc., and compare to the PTGM. The ultimate goal of this study is to provide commercial apple growers with scientific-based recommendations on the optimum initial application timing and the required frequency of reapplication of blossom thinning sprays.

\section{Materials and Methods}

\subsection{Plant Materials, Treatments and Experimental Design}

This project was initiated in 2019 and replicated at two sites. The experiment was performed at Virginia Tech's Alson H. Smith Jr. Agricultural Research and Extension Center in Winchester, VA, USA $\left(39^{\circ} 6^{\prime} 45^{\prime \prime} \mathrm{N}, 78^{\circ} 17^{\prime} 0.6^{\prime \prime} \mathrm{W}\right)$ and at the North Carolina State University's Mountain Horticultural Crops Research and Extension Center in Mills River, NC, USA $\left(35^{\circ} 25^{\prime} 31^{\prime \prime} \mathrm{N}, 82^{\circ} 33^{\prime} 88^{\prime \prime} \mathrm{W}\right)$. The weather data (e.g., average air temperature, total precipitation and relative humidity) during the bloom thinning application window were reported for both locations (Tables S1 and S2). The Winchester site utilized 'Crimson Gala' /'M.9' apple trees planted in 2000. Trees were planted at a $3 \mathrm{~m}$ by $5.5 \mathrm{~m}$ spacing and trained to a central leader system. In Mills River, 'Ultima Gala' /'M.9' apple trees planted in 2012 were used. Trees were planted at $0.9 \mathrm{~m}$ by $4 \mathrm{~m}$ spacing and trained to tall spindle. A total of five different treatments and an unthinned control were utilized at both sites (Table 1). In the course of the experiment, insecticide, fungicide, and nutrient management adhered to local recommendations. Furthermore, both research blocks received standard pruning/training procedures during the winter of 2018/2019. No other thinning methods were implemented in this experiment.

Table 1. Treatment schemes and application timings.

\begin{tabular}{|c|c|c|c|c|c|c|}
\hline \multirow{2}{*}{ No. } & \multicolumn{2}{|c|}{ Treatment Schemes $^{\mathrm{z}}$} & \multicolumn{2}{|c|}{ Winchester, Virginia $\mathrm{y}$} & \multicolumn{2}{|c|}{ Mills River North, Carolina ${ }^{x}$} \\
\hline & Spray \#1 & Spray \#2 & Spray \#1 & Spray \#2 & Spray \#1 & Spray \#2 \\
\hline \multirow{2}{*}{$1^{w}$} & \multirow{2}{*}{ PTGM } & \multirow{2}{*}{ PTGM } & $4 / 21 / 19$ & $4 / 23 / 19$ & $4 / 10 / 19$ & $4 / 12 / 19$ \\
\hline & & & $12: 30 \mathrm{AM}$ & 2:37 PM & 1:07 PM & $8: 25$ AM \\
\hline \multirow{2}{*}{$2^{v}$} & \multirow{2}{*}{$20 \mathrm{OB}$} & \multirow{2}{*}{$48 \mathrm{~h}$} & $4 / 18 / 19$ & $4 / 20 / 19$ & $4 / 9 / 19$ & $4 / 11 / 19$ \\
\hline & & & 12:48 PM & 8:47 PM & 8:45 AM & 8:43 AM \\
\hline \multirow{2}{*}{$3^{v}$} & \multirow{2}{*}{$20 \mathrm{OB}$} & \multirow{2}{*}{$72 \mathrm{~h}$} & $4 / 18 / 19$ & $4 / 21 / 19$ & $4 / 9 / 19$ & $4 / 12 / 19$ \\
\hline & & & 12:48 PM & 5:21 PM & $8: 45$ AM & $8: 25$ AM \\
\hline \multirow{2}{*}{$4^{v}$} & \multirow{2}{*}{$80 \mathrm{OB}$} & \multirow{2}{*}{$48 \mathrm{~h}$} & $4 / 20 / 19$ & $4 / 22 / 19$ & $4 / 13 / 19$ & $4 / 16 / 19$ \\
\hline & & & 8:47 PM & 7:40 PM & 5:00 PM & 9:07 AM \\
\hline \multirow{2}{*}{$5^{v}$} & \multirow{2}{*}{$80 \mathrm{OB}$} & \multirow{2}{*}{$72 \mathrm{~h}$} & $4 / 20 / 19$ & $4 / 23 / 19$ & $4 / 13 / 19$ & $4 / 17 / 19$ \\
\hline & & & 8:47 PM & 7:36 PM & 5:00 PM & 9:50 AM \\
\hline $6^{\mathrm{u}}$ & \multicolumn{2}{|c|}{ Control } & - & - & - & - \\
\hline
\end{tabular}

${ }^{\mathrm{z}}$ Each treatment received two blossom thinner spray applications. Both spray applications contained 2 NovaSource Lime Sulfur and 2 JMS Stylet Oil. Treatments differed according to application timing. ${ }^{y}$ Actual application timing of blossom thinning sprays at Winchester, Virginia site. ${ }^{x}$ Actual application timing of blossom thinning sprays at Mills River, North Carolina site. ${ }^{w}$ Spray application timing of treatment number 1 utilized the pollen tube growth model. The model was started once 20 of king blossoms were open. The model was started on 17 April 2019 at 10:00 AM in Winchester, Virginia and on 7 April 2019 at 7:00 PM in Mills River, North Carolina. The first spray application was targeted at the date/time when the pollen tube reached $100 \%$ the length of the style as predicted by the model. The second spray application was targeted at the date/time when the pollen tube reached $60-70 \%$ the length of the style as predicted by the model. ${ }^{\circ}$ Spray application timing for treatment numbers 2-5 was determined by pre-structured timing intervals. The first applications were targeted when $20 \%$ or $80 \%$ open blooms occurred and second applications where targeted at the 48-h or 72-h time marks following the first spray. ${ }^{u}$ Non-thinned control. No blossom thinning sprays, no fruit thinning sprays, no hand-thinning, etc. 


\subsection{Treatment \#1: PTGM and Spray Applications}

For treatment \#1, the PTGM was utilized to determine the application timing of the first and second sprays. At both sites the PTGM was started once $20 \%$ of the king blossoms were open. This was determined by daily visual observation. Prior to the starting the model, 50 blossoms were collected at random at each site in order to determine the average style length to be entered into the model. At the Winchester site, the average style length was $12.96 \mathrm{~mm}$ and at Mills River average style length was $9.77 \mathrm{~mm}$. At the Winchester site the first and second applications occurred when the estimated pollen tube growth was $114 \%$ and $57 \%$ the length of the style, respectively. At the Mills River site, the first application occurred when estimated pollen tube growth reached $95 \%$ the length of the style. The second application occurred when estimated pollen tube growth was $76 \%$ the length of the style (Table 1).

\subsection{Treatments \#2-5: Spray Applications}

Treatments \#2, \#3, \#4, and \#5 utilized pre-structured blossom thinning spray timings based upon the percentage of open bloom for initial sprays and fixed time intervals for subsequent sprays. To determine the percentage of open bloom, ten representative branches uniformly distributed in the research block at each site were selected. At the pink stage (code 57, BBCH-Scale) [24], all flower clusters on each branch were counted and multiplied by five (assuming five flowers per cluster) to determine the theoretical total number of flowers. Daily counts of the open flowers on each branch were performed starting at the late pink stage. The daily count of open flowers was then divided by the theoretical total number of flowers to determine the percentage of open flowers for each day.

The experiment had a complete randomized design (CRD) and was replicated five times. The experimental unit was a single-tree plot and buffer trees separated plots. The first and second blossom thinning sprays for all treatments consisted of spray solution containing: $2 \%$ NovaSource Lime Sulfur Solution (active ingredient: $29 \%$ calcium polysulfide) and 2\% JMS Stylet Oil (active ingredient: $97.1 \%$ paraffinic oil). Both sides of the trees were sprayed until thoroughly wetted. At the Winchester site, treatment spray applications started with an electric powered handgun sprayer (custom fabricated) mounted on the bed of a utility vehicle. At the Mills River site, a $\mathrm{CO}_{2}$ sprayer (Bellspray, Inc., Opelousas, LA, USA) mounted on the bed of a utility vehicle was used to apply the blossom thinning sprays.

\subsection{Fruit Set (\%) Assessments}

Fruit set differences between treatments was evaluated by flagging representative limbs to obtain approximately 100 flower clusters per replicate tree. At the Winchester site, three uniform branches per replicate tree were selected to obtain the $\sim 100$ flower clusters. At the Mills River site, 3-7 uniform limbs per replicate tree were selected to obtain the $\sim 100$ flower clusters. From the flagged flower clusters, the cluster count (i.e., 103 flower clusters) was multiplied by five (the average number of blossoms per cluster) to obtain the theoretical maximum fruit set (i.e., 515 fruit) on the flagged limbs of each replicate tree. Counts of the number of fruits on the flagged limbs of each replicate tree were performed two weeks, four weeks, six weeks, and eight weeks after petal fall and immediately prior to harvest. To obtain fruit set percentages, the fruitlet/fruit count from each respective time interval was divided by the theoretical maximum fruit set (i.e., 515 fruit).

\subsection{Fruit Yield and Fruit Quality Assessments}

Whole trees were harvested across two harvest events to mimic commercial management practice. All fruits were harvested except for any fruit which had obvious visual damage from excessive rot, herbicide injury, mechanical injury, etc. An electronic fruit sorter (Durand-Wayland, Inc., LaGrange, GA, USA) equipped with a color and infrared camera system and full transmittance spectrometer (TrueSort Electronics; Ellips, Eidhoven, The Netherlands) was used to determine: (1) fruit weight, (2) fruit diameter, (3) fruit length, 
and (4) the percentage of blush present on each fruit. From this data, the yield ( $\mathrm{kg}$ fruit/tree) per treatment and fruit count (\# fruit/tree) was calculated. The crop yield per acre was estimated using tree density (Winchester: 242 trees per acre; Mills River: 1092 trees per acre), the kilograms of harvested fruit per replicate tree, and a fixed bushel weight of $48 \mathrm{lbs}$. From the Winchester site, a total of 18,815 individual fruits were harvested from both picks and run through the sorter, while a total of 6040 individual fruits were harvested in Mills River. After running the fruit through the sorter, twenty fruits from each replicate were randomly selected for evaluating fruit russet incidence/severity. A russet rating scale adapted from the United States Standards for Grades of Apples was used (United State Department of Agriculture, 2002). Using the scale, the fruits were placed into one of three grade categories: Category 1 (USA Extra Fancy and U.S. Fancy grades) $0 \%$ russeting; Category 2 (U.S. No. 1 grade) 1-25\% smooth net-like russeting and/or 1-10\% smooth solid russeting; and Category 3 (U.S. Utility Grade) $>25 \%$ smooth net-like russeting and/or $>10 \%$ smooth solid russeting.

\subsection{Foliar Phytotoxicity}

Foliar phytotoxicity was visually rated using a $0-100$ scale with 0 indicating that $0 \%$ of the leaf surface was necrotic/chlorotic and 100 indicating that $100 \%$ of the leaf surface was necrotic/chlorotic. Four representative spurs (two from each side of the tree) were rated on each plot. When generating the phytotoxicity ratings, the entire surface area of all the leaves of each spur were considered.

\subsection{Statistical Analysis}

JMP Pro 14 was used for all statistical analysis. Tukey's honest significantly difference was used as the sole statistical method in evaluating significant difference between the treatments with regards to fruit set, crop density, yield, foliar phytotoxicity, fruit russeting, etc.

\section{Results}

\subsection{Effects of Thinning Strategies on Fruit Set and Yield}

The majority of the blossom thinning treatments reduced fruit set at the Winchester site (Table 2). All the blossom thinning strategies, except $80 \%$ open bloom +72 -h treatment, reduced fruit set significantly at harvest compared to the control. No significant effect on fruit set was observed when thinning timing was guided by the PTGM or scheduled applications. Differences in fruit set at harvest between treatments were more variable at the Mills River site. Only the PTGM treatment and $20 \%$ open bloom +48 h-treatment were found to have a mean fruit set at harvest which was both lower and significantly different from the control (Table 2). In both locations, fruit set data collected at early time points after petal fall (e.g., 2-8 WAPF) followed almost the same trend observed at harvest, indicating that blossom thinning treatment was the major source of variation observed among treatments.

All treatments at the Winchester site had lower yield $(\mathrm{kg} / \mathrm{tree})$ and lower fruit numbers per tree when compared to the control (Table 3). However, none were significantly different from the control. At the Mills River site, thinning treatments had no significant effect on tree yield (kg/tree) compared to control. However, the PTGM significantly reduced fruit number per tree when compared to the control (Table 3). The estimated yield per acre (bushels/acre) did not differ from the control in both sites, with one exception: the PTGM treatment was significantly different from the $80 \%$ open bloom +48 -h treatment and $80 \%$ open bloom +72 -h treatment in Mills River (Table 4). 
Table 2. Treatment effect on fruit set (\%) of 'Gala' apples. ${ }^{\mathrm{z}}$

\begin{tabular}{|c|c|c|c|c|c|}
\hline Treatment & 2 WAPF & 4 WAPF & 6 WAPF & 8 WAPF & At Harvest \\
\hline \multicolumn{6}{|c|}{ Fruit Set (\%) in Winchester, Virginia } \\
\hline PTGM & $30.0 \mathrm{bc}$ & $17.6 \mathrm{a}$ & $13.4 \mathrm{~b}$ & $12.7 \mathrm{~b}$ & $11.7 \mathrm{~b}$ \\
\hline $20 \mathrm{OB}+48 \mathrm{~h}$ & $25.7 \mathrm{c}$ & $12.0 \mathrm{~b}$ & $10.2 \mathrm{~b}$ & $9.8 \mathrm{~b}$ & $9.6 \mathrm{~b}$ \\
\hline $20 \mathrm{OB}+72 \mathrm{~h}$ & $25.6 \mathrm{c}$ & $11.9 \mathrm{~b}$ & $10.1 \mathrm{~b}$ & $9.4 \mathrm{~b}$ & $9.1 \mathrm{~b}$ \\
\hline $80 \mathrm{OB}+48 \mathrm{~h}$ & $37.6 \mathrm{ab}$ & $17.5 \mathrm{a}$ & $14.3 \mathrm{ab}$ & $13.6 \mathrm{ab}$ & $13.2 \mathrm{ab}$ \\
\hline $80 \mathrm{OB}+72 \mathrm{~h}$ & $32.9 \mathrm{abc}$ & $17.2 \mathrm{a}$ & $14.1 \mathrm{ab}$ & $13.4 \mathrm{ab}$ & $11.5 \mathrm{~b}$ \\
\hline Control & $44.0 \mathrm{a}$ & $21.4 \mathrm{a}$ & $18.6 \mathrm{a}$ & $17.5 \mathrm{a}$ & $16.3 \mathrm{a}$ \\
\hline \multicolumn{6}{|c|}{ Fruit Set (\%) in Mills River, North Carolina } \\
\hline PTGM & $29.4 \mathrm{~b}$ & $10.8 \mathrm{c}$ & $8.4 \mathrm{~b}$ & $8.3 \mathrm{~b}$ & $7.8 \mathrm{~b}$ \\
\hline $20 \mathrm{OB}+48 \mathrm{~h}$ & $38.2 \mathrm{ab}$ & $16.0 \mathrm{bc}$ & $10.0 \mathrm{~b}$ & $9.2 \mathrm{~b}$ & $8.8 \mathrm{~b}$ \\
\hline $20 \mathrm{OB}+72 \mathrm{~h}$ & $45.5 \mathrm{a}$ & $22.5 \mathrm{a}$ & $16.1 \mathrm{a}$ & $15.6 \mathrm{a}$ & $14.9 \mathrm{a}$ \\
\hline $80 \mathrm{OB}+48 \mathrm{~h}$ & $39.8 \mathrm{ab}$ & $22.7 \mathrm{a}$ & $15.3 \mathrm{a}$ & $15.0 \mathrm{a}$ & $14.5 \mathrm{a}$ \\
\hline $80 \mathrm{OB}+72 \mathrm{~h}$ & $41.8 \mathrm{ab}$ & $17.8 \mathrm{ab}$ & $12.0 \mathrm{ab}$ & $11.8 \mathrm{ab}$ & $10.9 \mathrm{ab}$ \\
\hline Control & $46.1 \mathrm{a}$ & $20.3 \mathrm{ab}$ & $14.3 \mathrm{a}$ & $13.6 \mathrm{a}$ & $13.2 \mathrm{a}$ \\
\hline
\end{tabular}

${ }^{\bar{z}}$ Mean separation within columns by Tukey's honest significant difference test in JMP Pro 14 at $\alpha=0.05$. Weeks after petal fall (WAPF), open bloom (OB), pollen tube growth model (PTGM).

Table 3. Treatment effect on number of fruit per tree and yield of 'Gala' apples. ${ }^{\mathrm{z}}$

\begin{tabular}{|c|c|c|c|c|}
\hline \multirow[b]{2}{*}{ Treatment } & \multicolumn{2}{|c|}{ Winchester, Virginia } & \multicolumn{2}{|c|}{ Mills River, North Carolina } \\
\hline & $\begin{array}{c}\text { Yield } \\
\left(\mathrm{kg} \text { Fruit/Tree) }{ }^{y}\right.\end{array}$ & Fruit No./Tree ${ }^{x}$ & $\begin{array}{c}\text { Yield } \\
(\mathrm{kg} \text { Fruit/Tree) }\end{array}$ & Fruit No./Treex \\
\hline PTGM & $72.4 \mathrm{a}$ & $596 a$ & $16.3 \mathrm{~b}$ & $119 \mathrm{c}$ \\
\hline $20 \mathrm{OB}+48 \mathrm{~h}$ & $65.5 \mathrm{a}$ & 518 a & $19.5 \mathrm{ab}$ & $153 \mathrm{bc}$ \\
\hline $20 \mathrm{OB}+72 \mathrm{~h}$ & $79.6 \mathrm{a}$ & $572 \mathrm{a}$ & $23.8 \mathrm{ab}$ & $207 \mathrm{ab}$ \\
\hline $80 \mathrm{OB}+48 \mathrm{~h}$ & $84.8 \mathrm{a}$ & 657 a & $28.2 \mathrm{a}$ & $217 \mathrm{ab}$ \\
\hline $80 \mathrm{OB}+72 \mathrm{~h}$ & $66.8 \mathrm{a}$ & $564 a$ & $28.5 \mathrm{a}$ & $284 \mathrm{a}$ \\
\hline Control & $93.8 \mathrm{a}$ & $855 \mathrm{a}$ & $27.2 \mathrm{ab}$ & $228 \mathrm{ab}$ \\
\hline
\end{tabular}

${ }^{\bar{z}}$ Mean separation within columns by Tukey's honest significant difference test in JMP Pro 14 at $\alpha=0.05$ y Kilograms of fruit/tree determined by entire tree harvest (two separate picks at both sites) and running fruit though sorter to obtain total weight of harvested fruit per replicate tree. ${ }^{\mathrm{x}}$ Number of fruit/tree determined by entire tree harvest (two separate picks at both sites) and running fruit though sorter to obtain the total number of fruits per replicate tree.

Table 4. Treatment effect on estimated yield (bushels/acre) of 'Gala' apples. ${ }^{\mathrm{z}}$

\begin{tabular}{|c|c|c|}
\hline Treatment & Winchester, Virginia ${ }^{y}$ & Mills River, North Carolina ${ }^{x}$ \\
\hline PTGM & $805 a$ & $820 b$ \\
\hline $20 \mathrm{OB}+48 \mathrm{~h}$ & $728 \mathrm{a}$ & $978 \mathrm{ab}$ \\
\hline $20 \mathrm{OB}+72 \mathrm{~h}$ & $885 \mathrm{a}$ & $1193 \mathrm{ab}$ \\
\hline $80 \mathrm{OB}+48 \mathrm{~h}$ & 943 a & 1415 a \\
\hline $80 \mathrm{OB}+72 \mathrm{~h}$ & $742 \mathrm{a}$ & 1429 a \\
\hline Control & $1042 \mathrm{a}$ & $1363 \mathrm{ab}$ \\
\hline
\end{tabular}

${ }^{\mathrm{z}}$ Mean separation within columns by Tukey's honest significant difference test in JMP Pro 14 at $\alpha=0.05$. y Estimated yield calculated using tree density (242 trees per acre), kilograms of harvested fruit per replicate tree, and a fixed bushel weight of $48 \mathrm{lbs}$. ${ }^{x}$ Estimated yield calculated using tree density (1092 trees per acre), kilograms of harvested fruit per replicate tree, and a fixed bushel weight of $48 \mathrm{lbs}$.

\subsection{Effects of Thinning Strategies on Fruit Quality \& Foliar Phytotoxicity}

At both sites, each treatment was significantly different from the control with regards to fruit weight $(\mathrm{g})$, diameter $(\mathrm{mm})$, and length $(\mathrm{mm})$ (Table 5). Furthermore, the significant differences of fruit weight, diameter, and length were consistent in each treatment at each respective site. Despite the presence of significant differences between treatments and the control, there was no clear relation between initial spray application timing ( $20 \%$ open bloom vs. $80 \%$ open bloom) nor reapplication frequency ( $48 \mathrm{~h}$ vs. $72 \mathrm{~h}$ ) and fruit size, diameter, and weight at either location (Table 5). 
Table 5. Treatment effect on individual fruit weight, diameter, length, and blush of 'Gala' apples. ${ }^{\mathrm{z}}$

\begin{tabular}{|c|c|c|c|c|}
\hline Treatment & Weight (g) y & Diameter (mm) y & Length $(\mathrm{mm})^{y}$ & Blush $\mathrm{y}$ \\
\hline \multicolumn{5}{|c|}{ Winchester, Virginia $\mathrm{x}$} \\
\hline PTGM & $121 \mathrm{~d}$ & $64.15 \mathrm{~d}$ & $60.75 \mathrm{~d}$ & $56.66 \mathrm{a}$ \\
\hline $20 \mathrm{OB}+48 \mathrm{~h}$ & $126 \mathrm{c}$ & $65.08 c$ & $61.53 c$ & $57.11 \mathrm{a}$ \\
\hline $20 \mathrm{OB}+72 \mathrm{~h}$ & $139 \mathrm{a}$ & $67.48 \mathrm{a}$ & $64.23 \mathrm{a}$ & $54.23 \mathrm{bc}$ \\
\hline $80 \mathrm{OB}+48 \mathrm{~h}$ & $129 \mathrm{~b}$ & $65.70 \mathrm{~b}$ & $62.50 \mathrm{~b}$ & $53.48 \mathrm{c}$ \\
\hline $80 \mathrm{OB}+72 \mathrm{~h}$ & $118 \mathrm{e}$ & $63.65 \mathrm{e}$ & $60.15 \mathrm{e}$ & $56.04 \mathrm{ab}$ \\
\hline Control & $110 \mathrm{f}$ & $61.83 \mathrm{f}$ & $58.74 \mathrm{f}$ & $56.69 \mathrm{a}$ \\
\hline \multicolumn{5}{|c|}{ Mills River, North Carolina w } \\
\hline PTGM & $138 \mathrm{a}$ & $66.98 \mathrm{a}$ & $64.53 \mathrm{a}$ & $65.87 \mathrm{a}$ \\
\hline $20 \mathrm{OB}+48 \mathrm{~h}$ & $127 b$ & $65.15 b$ & $62.53 \mathrm{~b}$ & $66.66 \mathrm{a}$ \\
\hline $20 \mathrm{OB}+72 \mathrm{~h}$ & $115 \mathrm{~d}$ & $62.35 \mathrm{~d}$ & $59.92 \mathrm{~d}$ & $52.95 \mathrm{c}$ \\
\hline $80 \mathrm{OB}+48 \mathrm{~h}$ & $130 \mathrm{~b}$ & $65.56 \mathrm{~b}$ & $62.81 \mathrm{~b}$ & $59.24 b$ \\
\hline $80 \mathrm{OB}+72 \mathrm{~h}$ & $100 \mathrm{e}$ & $58.96 \mathrm{e}$ & $56.66 \mathrm{e}$ & $49.24 \mathrm{~d}$ \\
\hline Control & $119 \mathrm{c}$ & $63.47 c$ & $61.07 \mathrm{c}$ & $47.71 \mathrm{~d}$ \\
\hline
\end{tabular}

${ }^{\mathrm{z}}$ Mean separation within columns by Tukey's honest significant difference test in JMP Pro 14 at $\alpha=0.05$ y Individual fruit weight, diameter, length, and blush determined by entire tree harvests (two separate picks) at both sites and running all harvested fruit though sorter. ${ }^{x}$ Data were obtained from a total of 18,815 individual fruits harvested from all treatment trees and control trees at Winchester, Virginia site. ${ }^{\mathrm{w}}$ Data were obtained from a total of 6040 individual fruits harvested from all treatment trees and control trees at Mills River, North Carolina site.

The treatments at the Winchester site did not have a substantial effect on fruit blush (Table 5). However, $20 \%$ open bloom +72 -h treatment and the $80 \%$ open +48 -h treatment slightly decreased the percentage of fruit blush and were significantly different from the control. At the Mills River site, most thinning treatments increased fruit blush coverage when compared to the control (Table 6). The exception was the $80 \%$ open bloom $+72-\mathrm{h}$ treatment, which did not differ from the control. Furthermore, the Mills River data collectively showed that fruit blush increased with earlier initial application timing and more frequent reapplication.

Table 6. Treatment effect on fruit packout according to fruit russet incidence/severity.

\begin{tabular}{|c|c|c|c|}
\hline Treatment & U.S Extra Fancy and U.S Fancy ${ }^{x}$ & U.S. No. $1^{\mathrm{w}}$ & U.S. Utility \\
\hline \multicolumn{4}{|c|}{ Winchester, Virginia } \\
\hline PTGM & $51 \mathrm{c}$ & $48 \mathrm{a}$ & $1 \mathrm{a}$ \\
\hline $20 \mathrm{OB}+48 \mathrm{~h}$ & $58 \mathrm{bc}$ & $42 \mathrm{a}$ & $0 \mathrm{a}$ \\
\hline $20 \mathrm{OB}+72 \mathrm{~h}$ & $70 \mathrm{abc}$ & $29 \mathrm{ab}$ & $1 \mathrm{a}$ \\
\hline $80 \mathrm{OB}+48 \mathrm{~h}$ & $77 \mathrm{ab}$ & $22 b$ & $1 \mathrm{a}$ \\
\hline $80 \mathrm{OB}+72 \mathrm{~h}$ & $63 \mathrm{abc}$ & $36 a b$ & $1 \mathrm{a}$ \\
\hline Control & $82 \mathrm{a}$ & $18 \mathrm{~b}$ & $0 \mathrm{a}$ \\
\hline \multicolumn{4}{|c|}{ Mills River, North Carolina } \\
\hline PTGM & $48 \mathrm{a}$ & $44 \mathrm{a}$ & $8 \mathrm{a}$ \\
\hline $20 \mathrm{OB}+48 \mathrm{~h}$ & $54 \mathrm{a}$ & $41 \mathrm{a}$ & $5 a$ \\
\hline $20 \mathrm{OB}+72 \mathrm{~h}$ & $36 a$ & $61 \mathrm{a}$ & $3 a$ \\
\hline $80 \mathrm{OB}+48 \mathrm{~h}$ & $39 a$ & $53 a$ & $8 \mathrm{a}$ \\
\hline $80 \mathrm{OB}+72 \mathrm{~h}$ & $52 \mathrm{a}$ & $45 \mathrm{a}$ & $3 a$ \\
\hline Control & $46 a$ & $49 \mathrm{a}$ & $5 \mathrm{a}$ \\
\hline
\end{tabular}

${ }^{\mathrm{z}}$ Mean separation within columns by Tukey's honest significant difference test in JMP Pro 14 at $\alpha=0.05$. y Packout according to fruit russet incidence/severity was determined using a 20-fruit subsample per replicate and assigning each individual fruit into a USDA apple grade based upon the incidence/severity of russet on the fruit as according to the USDA apple grade standards. ${ }^{x}$ U.S. Extra Fancy and U.S. Fancy Grades criteria: 0 russeting. ${ }^{\text {w }}$ U.S. No. 1 Grade criteria: $1-25$ smooth net-like russeting and/or 1-10 smooth solid russeting. ${ }^{\mathrm{v}}$ U.S Utility Grade criteria: greater than 25 smooth net-like russeting and/or greater than 10 smooth solid russeting.

All the treatments from the Winchester site had lower mean packouts of U.S. Extra Fancy/U.S. Fancy grade fruit and higher proportions of U.S. No. 1 grade fruit due to the incidence and severity of russet (Table 6). The PTGM treatment and the 20\% open bloom +48 -h treatment both had lower mean percentages of U.S. Extra Fancy/U.S. Fancy 
grade fruit and higher mean percentages of U.S. No. 1 grade fruit which were significantly different from the control at the Winchester site. There was no significant difference in the proportion of fruit classified in the U.S. Utility grade at the Winchester site. At the Mills River site, blossom thinning treatments has no significant effects on fruit packout compared to control. Additionally, no significant differences were observed among thinning strategies (Table 6).

At the Winchester site, all thinning treatments increased the incidence of phytotoxicity with most of them being significantly different from the control (Table 7). The Winchester treatments suggested that phytotoxicity incidence increased with later initial applications. However, there was no significant difference between the phytotoxicity ratings of earlier initial applications when compared to the later initial applications. At Mills River thinning treatments increased phytotoxicity incidence but were not significant when compared to the control. However, only the PTGM treatment showed significantly higher levels of foliar phytotoxicity (Table 7).

Table 7. Treatment effect on phytotoxicity $z, y$.

\begin{tabular}{ccc}
\hline Treatment & Winchester, Virginia & Mills River, North Carolina \\
\hline PTGM & $1.8 \mathrm{a}$ & $16.0 \mathrm{a}$ \\
$\mathbf{2 0}$ OB $+\mathbf{4 8} \mathbf{~ h}$ & $1.8 \mathrm{a}$ & $8.0 \mathrm{~b}$ \\
$\mathbf{2 0}$ OB $+72 \mathrm{~h}$ & $1.7 \mathrm{ab}$ & $5.8 \mathrm{~b}$ \\
$\mathbf{8 0}$ OB $+\mathbf{4 8} \mathrm{h}$ & $2.6 \mathrm{a}$ & $6.5 \mathrm{~b}$ \\
$\mathbf{8 0}$ OB $+\mathbf{7 2} \mathrm{h}$ & $3.0 \mathrm{a}$ & $4.3 \mathrm{~b}$ \\
Control & $0.2 \mathrm{~b}$ & $5.0 \mathrm{~b}$ \\
\hline
\end{tabular}

$\overline{\mathrm{z}}$ Mean separation within columns by Tukey's honest significant difference test in JMP Pro 14 at $\alpha=0.05$ y Phytotoxicity evaluated by selecting four leaf spurs per replicate and visually assessing the percentage of chlorotic/necrotic leaf area present on the upper surface area of the leaves present on each spur. Phytotoxicity expressed as the percentage of leaf area affected by chlorosis and/or necrosis.

\section{Discussion}

\subsection{Fruit Set and Yield as Affected by Thinning Spray Timing}

This study demonstrated that use of the 'Gala' PTGM reduced fruit set, yield, fruit number, and estimated yield per acre at both sites in most cases (Tables 2-4). This is in agreement with other research studies $[18,25]$ which demonstrate that the PTGM is a reliable method for timing blossom thinning sprays. Additionally, lime sulfur sprays applied at $20 \%$ open bloom and $48 \mathrm{~h}$ later performed near equally well as the PTGM treatment in reducing fruit set, crop density, $\mathrm{kg}$ fruit/tree, fruit no/tree, and estimated yield per acre in most situations. Blossom thinning sprays need to be applied early enough to prevent excessive fruit set [26], which could also explain why the $20 \%$ open bloom +48 -h treatment performed as well as the PTGM. This treatment also performed well likely due to the short reapplication frequency $(48 \mathrm{~h})$. Since temperature directly impacts pollen tube growth which, in turn, influences the time required for fertilization [19], shorter spray intervals are more likely to decrease the chances of flower fertilization and preventing fruit set. The other treatments with more delayed reapplication frequencies and later initial sprays were found to be not as effective in reducing the factors affecting yield such as fruit set, crop density, etc.

With regards to reapplication frequency of the treatments with an initial application at $20 \%$ open bloom, it was found that the treatment with an initial application at $20 \%$ open bloom and $72 \mathrm{~h}$ thereafter was effective in reducing fruit set at the Winchester site but not in Mills River. Although temperature plays a major role in determining fertilization timing [19], there were minor differences in mean hourly temperature between the time of the first and second sprays for the $20 \%$ open bloom +72 -h treatment at the two sites (Winchester $62.9^{\circ} \mathrm{F}$ and Mills River $61.3^{\circ} \mathrm{F}$ ). Consequently, differences in fruit set between Winchester site and Mills River site were likely due to other variable(s) affecting the time required for flower fertilization, such as style length. Indeed, at the Winchester site, the mean style length was found to be $12.96 \mathrm{~mm}$ compared to the shorter $9.77 \mathrm{~mm}$ style length 
at the Mills River location. Since longer style length has been shown to be associated with more time required for flower fertilization [20,27], it is likely that the shorter style length at the Mills River site allowed the pollen tubes to reach the base of the style, resulting in flower fertilization prior to the second spray in the $20 \%$ open bloom treatment, thereby, rendering the second spray ineffective in thinning the flowers and causing the treatment to have a higher fruit set. Additionally, pollen tube growth rates and the associated time required for fertilization have shown to be influenced by other factors such as paternal pollen source $[20,27]$. With the research sites having different adjacent blocks containing different production and pollinizer cultivars, the dominant paternal pollen source was likely different between the two sites and may have also had a role in affecting the time required for flower fertilization.

Later initial applications at $80 \%$ open bloom were not reliably effective in reducing fruit set, $\mathrm{kg}$ fruit/tree, fruit no./tree, nor estimated bu./acre (Tables 2-4). This likely resulted from the additional time allowed for the majority of the blossoms to open and become fertilized, thereby rendering the blossom thinning sprays less effective. Finally, there was no significant difference in fruit set, yield, fruit no./tree, and estimated bu./acre (Tables 2-4) between the reapplication frequencies ( $48 \mathrm{~h}$ vs. $72 \mathrm{~h}$ ) of the treatments with an initial application at $80 \%$ open bloom. This likely resulted from the increased crop load which could have minimized significant difference. Delayed second applications in the $80 \%$ open bloom treatments at the Mills River site could have contributed to this limited treatment responses.

\subsection{Effects of Thinning Timing Strategies on Fruit Quality, Packout and Phytotoxicity}

Despite the large number of data points (18,815 fruits from the Winchester site and 6040 fruits from the Mills River site) and the presence of significant difference between treatments and the control, there was no clear relationship effect of initial application timing (i.e., $20 \%$ open bloom vs. $80 \%$ open bloom) nor reapplication frequency (i.e., $48 \mathrm{~h}$ vs. $72 \mathrm{~h}$ ) on individual fruit weight, diameter, or length across both sites (Table 5). At the Winchester site, lime sulfur treatments had higher mean fruit weights, diameters, and lengths which were significantly different from the control, suggesting that all of the treatments had a thinning effect. This agrees with other recent studies $[18,24,28-30]$ which showed that increased thinning (i.e., reduced fruit set, reduced crop load, etc.) increased fruit weight/size when lime sulfur was used as a blossom thinner. At the Mills River site, all the treatments, with the exception of the $20 \%$ open bloom +72 -h treatment and $80 \%$ open bloom +72 -h treatment, had significantly higher mean weights, diameters, and lengths than the control (Tables 2-6). This likely resulted from the short style length $(9.77 \mathrm{~mm}$ ) as explained above. At both sites, the PTGM treatment and the other treatments with a reapplication interval of $48 \mathrm{~h}$ all had significantly higher mean fruit weights, diameters, and lengths compared to the control. With effective thinning applications shifting the fruit weight distribution from lower size categories to higher size categories [31], it is suggested that the PTGM and 48-h reapplication treatments had an effective thinning effect.

Effects on fruit blush were inconsistent. The $20 \%$ open bloom +72 -h and $80 \%$ open bloom +48 -h treatments slightly decreased fruit blush at the Winchester site. In comparison, the Mills River data suggested that fruit blush increased with earlier initial application timing and more 48-h reapplication timing (Tables 2-6). Bound [29] demonstrated that lime sulfur blossom thinning sprays with heavier thinning increased fruit background color. With a negative linear relationship existing between crop load and fruit color [31], it is suggested that the earlier initial application time (i.e., $20 \%$ open bloom) and more frequent reapplication frequencies (i.e., $48 \mathrm{~h}$ ) of blossom thinning sprays can result in more thinning, thereby increasing fruit color. Evidence of this trend is generally supported by the Mills River fruit set data (Table 2). However, this relationship between application timing and fruit blush was not observed at the Winchester site. This could have resulted from sub-clonal differences ('Ultima Gala' vs. 'Crimson Gala') and/or the training system differences (high density vs. medium density) between the two sites. 
Lime sulfur blossom thinning sprays is performed during the most sensitive time of development for the induction of russeting [31]. Fruit packout from russet incidence/severity was not conclusive between the two sites. At the Winchester site, all lime sulfur treatments had lower mean packouts of U.S. Extra Fancy/U.S. Fancy grade fruit and higher proportions of U.S. No. 1 grade fruit due to the incidence and severity of russet, though not always significant (Table 6). On the contrary, lime sulfur sprays had no impact on fruit russeting incidence/severity and consequential impact on the packout of higher-grade fruit in Mills River, despite some treatments being applied during poor drying conditions (Table S2) and/or later than desired. Lime sulfur effects on fruit russeting has varied between different studies and is likely dependent on multiple factors. Stopar [30] found that increasing concentrations of lime sulfur did not increase the occurrence of fruit russet, whereas Peck et al. [25] found that model-guided lime sulfur blossom thinning sprays resulted in a significant increase of fruit russet incidence. The adjuvant used in lime sulfur sprays can also have significant impacts on fruit russet incidence [29]. Furthermore, it has been suggested that climatic factors such as humidity can have an influence on russet incidence/severity [32]. The results from this study suggested that there was no conclusive effect of lime sulfur blossom thinning spray timing and humidity on russet incidence/severity (Table 6). However, it is likely that variables such as canopy density and training systems that were different between the two sites could explain the difference in fruit russet incidence/severity between the two sites.

Some lime sulfur treatments slightly increased incidences of foliar phytotoxicity compared to the control (Table 7). However, the PTGM treatment at the Mills River site showed an exceptionally high level of phytotoxicity compared to other treatments at both sites. This likely a result of poor weather conditions during the time of application, as light rain (0.34 inch) occurred during application (Table S2). Slow drying conditions caused by low light, high humidity, and temperatures above $85^{\circ} \mathrm{F}$ around the time of application have potential for causing foliar phytotoxicity from lime sulfur blossom thinning sprays [11]. Overall, there was no clear relationship between lime sulfur blossom thinning spray timing and phytotoxicity incidence. Although lime sulfur blossom thinning sprays have been associated with increased foliar phytotoxicity in some studies [30], other studies [18] have shown that lime sulfur results in minimal foliar phytotoxicity and other blossom thinners, such as ammonium thiosulphate, can result in more excessive phytotoxicity. From the results of this study, it can be suggested that lime sulfur sprays applied during bloom have the potential to result in increased foliar phytotoxicity with little to no influence from the application timing.

\section{Conclusions}

This study found that the 'Gala' PTGM was effective in timing blossom thinning application, which resulted in reduced fruit set and increased fruit weight and size across two locations. Additionally, we demonstrated that treatments with an initial application applied at $20 \%$ open bloom and $48 \mathrm{~h}$ thereafter were nearly equally effective as the PTGM treatment in reducing fruit set and increasing individual fruit weight and size. Other treatments with a later initial application at $80 \%$ open bloom and more delayed second sprays (i.e., $72 \mathrm{~h}$ after the initial spray) were not effective or consistent. The data from this study did not conclusively suggest a relationship between lime sulfur blossom thinning spray timing and fruit russet incidence/severity and foliar phytotoxicity. Likely, other factors such as humidity, drying time, and climate could impact the crop safety of lime sulfur blossom thinning sprays more than application timing. From this study, it is suggested that growers wishing to adopt chemical blossom thinning as a main thinning practice should use the PTGM if feasible. However, if growers cannot use the PTGM this project demonstrates that lime sulfur sprays applied at $20 \%$ open bloom and $48 \mathrm{~h}$ thereafter may result in a similar thinning outcome. Although this project only evaluated lime sulfur blossom thinning spray timing, growers must also consider other variables such as rates, surfactant, and the number of applications when planning a lime sulfur blossom thinning 
spray program. These additional considerations are critical and should be thoroughly evaluated in future applied research studies.

Supplementary Materials: The following are available online at https://www.mdpi.com/article/ 10.3390/horticulturae7090308/s1, Table S1: Weather Data for the Alson H. Smith Jr. Agricultural Research and Extension Center in Winchester, Virginia (1-30 April 2019). ${ }^{z}$; Table S2: Weather Data for the Mountain Horticultural Crops Research and Extension Center in Mills River, North Carolina (1-30 April 2019) ${ }^{\mathrm{z}}$.

Author Contributions: Conceptualization, W.C.A. and S.M.S.; methodology, W.C.A., T.K. and S.M.S.; investigation, W.C.A.; writing—original draft preparation, W.C.A.; writing-review and editing, T.K. and S.M.S.; supervision, S.M.S.; project administration, S.M.S.; funding acquisition, S.M.S. All authors have read and agreed to the published version of the manuscript.

Funding: This research was funded by Virginia-Specialty Crop Block Grant Program (SCBGP), grant number: 418608, and Specialty Crop Research Initiative (SCRI), grant number: 419385.

Acknowledgments: The authors would like to thank Sara Pitcock, Mariah Temkin, and Chistopher Clavet for their assistance with collecting and recording data for fruit set, yield, and fruit quality assessments.

Conflicts of Interest: The authors declare no conflict of interest.
Abbreviations
OB Open bloom
PTGM Pollen tube growth model

\section{References}

1. Way, R.D. Pollination \& Fruit Set of Fruit Crops. Cornell Ext. Bul. 1978, 237, 1-15.

2. Embree, C.G.; Myra, M.T.; Nichols, D.S.; Wright, A.H. Effect of blossom density and crop load on growth, fruit quality, and return bloom in 'Honeycrisp'apple. HortScience 2007, 42, 1622-1625. [CrossRef]

3. Serra, S.; Leisso, R.; Giordani, L.; Kalcsits, L.; Musacchi, S. Crop load influences fruit quality, nutritional balance, and return bloom in 'Honeycrisp'apple. HortScience 2016, 51, 236-244. [CrossRef]

4. Stover, E.; Fargione, M.; Risio, R.; Yang, X.; Robinson, T. Fruit weight, crop load, and return bloom of' Empire' apple following thinning with 6-benzyladenine and NAA at several phenological stages. HortScience 2001, 36, 1077-1081. [CrossRef]

5. Allen, W.C.; Sherif, S.M. Chemical Blossom Thinning in Virginia Apple Orchards. V. A. Coop. Ext. Bul. 2019, SPES-110-NP, 1-2.

6. Byers, R.E.; Carbaugh, D.H. Effect of Chemical Thinning Sprays on Apple Fruit Set. J. Am. Soc. Hort. Sci. 1991, 1, 41-48. [CrossRef]

7. McArtney, S.J.; Tustin, D.S.; Seymour, S.; Cashmore, W.; Looney, N.E. Benzyladenine and carbaryl effects on fruit thinning and the enhancement of return flowering of three apple cultivars. J. Hortic. Sci. 1995, 70, 287-296. [CrossRef]

8. Wertheim, S.J. Developments in the chemical thinning of apple and pear. Plant Growth Regul. 2000, 31, 85-100. [CrossRef]

9. Yuan, R. Effects of temperature on fruit thinning with ethephon in 'Golden Delicious' apples. Sci. Horti. 2007, 113, 8-12. [CrossRef]

10. Black, B.L.; Petracek, P.D.; Bukovac, M.J. The effect of temperature on uptake of NAA by RedchiefDelicious'apple leaves. J. Am. Soc. Hort. Sci. 1995, 120, 441-445. [CrossRef]

11. Schupp, J.R.; Kon, T.M. Apple Crop Load Management: Blossom Thinning Apples with Lime Sulfur. Penn. State Coop. Ext. Bul. 2019, ART-770, 1-8.

12. Williams, M.W. Sulfcarbamide, a Blossom-Thinning Agent for Apples. Hort. Tech. 1993, 3, 322-324. [CrossRef]

13. Greene, D.W. Blossom Thinning as a Strategy in Chemical Thinning of Apples in New England. Acta Hortic. 2004, 636, 331-337. [CrossRef]

14. Williams, M.W. New Chemical Approaches for Control of Biennial Bearing of Apples. Bioregulators for Crop Protection and Pest Control. In Bioregulators for Crop Protection and Pest Control; ACS Symposiums Series; American Chemical Society: Washington, DC, USA, 1994.

15. Williams, M.W.; Bound, S.A.; Hughes, J.; Tustin, S. Endothall: A Blossom Thinner for Apples. Hort. Tech. 1995, 5, 257-259. [CrossRef]

16. Schupp, J.R.; McFerson, J.R.; Robinson, T.L. Alternative to Fish Oil for Thinning Apples with Lime Sulfur. HortScience 2005, 40, 1117. [CrossRef]

17. Dennis, F.G. The History of Fruit thinning. Plant Growth Reg. 2000, 31, 1-16. [CrossRef]

18. Kon, T.M.; Schupp, J.R.; Yoder, K.S.; Combs, L.D.; Schupp, M.A. Comparison of Chemical Blossom Thinners Using 'Golden Delicious' and 'Gala' Pollen Tube Growth Models as Timing Aids. HortScience 2018, 53, 1143-1151. [CrossRef] 
19. Yoder, K.; Yuan, R.; Combs, L.; Byers, R.; McFerson, J.; Schmidt, T. Effects of Temperature and the Combination of Liquid Lime Sulfur and Fish Oil on Pollen Germination, Pollen Tube Growth, and Fruit Set in Apples. HortScience 2009, 44, $1277-1283$. [CrossRef]

20. Delong, C.N.; Yoder, K.S.; Combs, L.; Veilleux, R.E.; Peck, G.M. Apple Pollen Tube Growth Rates Are Regulated by Parentage and Environment. J. Am. Soc. Hort. Sci. 2016, 141, 548-554. [CrossRef]

21. Yoder, K.S.; Peck, G.M.; Combs, L.D.; Byers, R.E. Using a Pollen Tube Growth Model to Improve Apple Bloom Thinning for Organic Production. Acta Hort. 2013, 100, 207. [CrossRef]

22. Johnson, J.; Courtney, R. Researchers Finish Final Pollen Tube Model. Good Fruit Grower, 29 March 2018.

23. Peck, G.; Olmstead, D. Implementing the pollen tube growth model on NEWA. Fruit Q. 2018, 26, 11-15.

24. Meier, U. Growth Stages of Mono- and Dicotyledonous Plants; BBCH Monograph; Federal Biological Research Centre for Agriculture and Forestry: Berlin/Braunschweig, Germany, 2001.

25. Peck, G.M.; DeLong, C.N.; Combs, L.D.; Yoder, K.S. Managing Apple Crop Load and Diseases with Bloom Thinning Applications in an Organically Honeycrisp' /'MM.111' Orchard. HortScience 2017, 52, 377-381. [CrossRef]

26. Bound, S.A.; Jones, K.M. Ammonium Thiosulphate as a Blossom Thinner for 'Delicious' Apple, 'Winter Cole' Pear, and 'Hunter' Apricot. Aust. J. Exp. Agr. 2004, 44, 931-937. [CrossRef]

27. Jahed, K.R.; Hirst, P.M. Pollen Tube Growth and Fruit Set in Apple. J. Am. Soc. Hort. Sci. 2017, 54, 1054-1059. [CrossRef]

28. Marchioretto, L.D.R.; De Rossi, A.; do Amaral, L.O.; de Souza Ribeiro, A.M.A. Efficacy and mode of action of blossom thinners on 'Fuji More' apple trees. Sci. Hortic. 2019, 246, 634-642. [CrossRef]

29. Bound, S.A. Alternate Thinning Chemicals for Apple. Acta Hort. 2010, 884, 229-236. [CrossRef]

30. Stopar, M. Vegetable Oil Emulsions, $\mathrm{NaCl}, \mathrm{CH}_{3} \mathrm{COOH}$, and $\mathrm{CaSx}$ as Organically Acceptable Apple Blossom Thinning Compounds. Europ. J. Hort. Sci. 2008, 73, 55-61.

31. Link, H. Significance of flower and fruit thinning on fruit quality. Plant Growth Regul. 2000, 31, 17-26. [CrossRef]

32. Creasy, L.L. The correlation of weather parameters with russet of 'Golden Delicious' apples under orchard conditions. J. Am. Soc. Hort. Sci. 1980, 105, 735-738. 